\title{
ЭГЭЛ НАРСАН ОЙН УРИЙН ТАЛБАЙН ХӨРСНИЙ ШИНЖ ЧАНАРЫН СУДАЛГАА
}

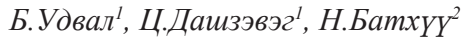 \\ ${ }^{1}$ Газарзуй-Геоэкологийн хүрээлэн, Шинжлэх ухааны Академи, Монгол улс \\ ${ }^{2}$ ХУрээлэн буй орчин судлал, химийн инженерчлэлийн тэнхим, ХШУИС, МУИС \\ Цахим шуудан: bayarsaikhanudval@gmail.com
}

\begin{abstract}
Scots pine (Pinus sylvestris L.) is the one of the most important economic timber species even their distribution is very limited in Mongolia compared with Larix sibirica. P. sylvestris stand cover only 5\% of total forest cover of Mongolia and distributes in subtaiga elevational zone. Forest resources in Mongolia have been continuously degraded over the past few years due to improper exploitation for timber and fuel wood (both permitted and illegal), forest and steppe fires [18], insects/pests and diseases, mining, uncontrolled grazing, and inadequate management. Hence, conservation of Scots pine forests which have very limited distribution is very important for this region. The study sites are located in Tujiin nars area, Altanbulag soum, Selenge province in the transitional zone where the mountainous zone around Lake Baikal changes to the Northern Mongolian highlands and are parts of the northern mountain range.

Analysis of soil physical and chemical properties shown that seed stands with site index II has more humus accumulation (1.32\%) than that of seed stands with sites index III $(0.73 \%)$ and IV (0.65\%), respectively, which suggests that site index or growth condition of forest stands which subjected as seed collection stands should be classified as site index II or III, accordingly.
\end{abstract}

Tүлхүур уг: үрийн модод, үрийн талбай, хөрсний шинж чанар, үрлэлт

\section{ОРШИЛ}

Эгэл нарсан ой манай улсын нутаг дэвсгэрийн умард хэсэгт гол төлөв Дорнод, Хэнтий, Төв, Сэлэнгэ, Булган, Хөвсгөл зэрэг аймгийн нутагт 514.4 мянган га талбайд тархсан бөгөөд судалгааны бүс нутагт 276.3 мянган га буюу $53.7 \%$ нь тархан ургаж байна.

Эгэл нарс (Pinus sylvestris L.) нь хот суурин, замд ойрхон, харьцангуй нам газарт ургадгаас түймэр, огтлолтонд их хэмжээгээр өртөж, сүүлийн жилүүдэд нөөц нь ихээхэн хувиар багассан ба 1986,
1989, 1992, 1995, 1997, 1998, 2002 онуудад гарсан их хэмжээний ойн талбайг хамарсан түймэр, хууль бус эмх замбараагүй мод огтлолтын нөлөөгөөр судалгааны бүс нутаг дахь нарсан ойн 70 орчим хувь нь устсан байна. Тус бүс нутагт ой ашиглалтанд хавтгайруулан огтлох аргыг хэрэглэсний улмаас тухайн ойд сайн чанарын үрийн модгүй болсон нь байгалийн аясаар нөхөн сэргэх боломж хязгаарлагдан тухайн орчинд хээрших үйл явц эрчимжиж, ойн ургамлан бүлгэмдэл хээрийн ургамлын бүлгэмдлээр 
солигдож, байгалийн тэнцвэр үндсэндээ алдагдсан байна [13]. Угийн бага нөөцтэй эгэл нарсан ой ийнхүу нөөцийн хувьд үлэмж хэмжээгээр хорогдсон нь түүнийг хамгаалахын зэрэгцээ зориудаар тарьж

\section{СУДАЛГААНЫ ЗОРИЛГО}

Өвөр Байгалийн ой ургамалжилтын мужийн Сэлэнгийн хошууны нөхцөлд yp бэлтгэж байгаa ойн хөрсний шинж чанарын үзүүлэлтүүдийг илрүүлэх, улмаар

\section{СУДАЛГААНЫ ОБЪЕКТ}

Энэхүу судалгааг Сэлэнгэ аймгийн Алтанбулаг сумын Тужийн нарсан ойн бүс нутагт гүйцэтгэсэн. Тус бүс нутаг нь И.А.Коротковын [7] ангиллаар Өмнөд өвөр Байгалийн ой ургамалжилтын мужийн Баруун Хэнтийн хошуунд, Г.Цэдэндашийн [14] ангиллаар Өмнөд Өвөр байгалийн

\section{СУДАЛГААНЫ АРГАЗУЙ}

Судалгааны дээж талбайг тусгаарлах, моддын таксацийн үндсэн үзүүлэлтийг тодорхойлоход Н.П.Анучины [1] арга зүйгээр, үрлэлтийн байдлыг А.А. Корчагины [8] аргаар үнэлэв. Үрийн чанарын үзүүлэлтүүдийг тодорхойлохдоо олон улсын үр шинжилгээний журам [17], Монгол улсын мод, сөөгний үрийг шинжлэх стандарт (MNS 2430:2009; MNS 2432:2009; MNS 2887:2009; MNS 5994:2009)-ыг үндэслэл болгов $[17,11]$.

Хөрсний зүсэлт хийх газрыг сонгохдоо тухайн талбайн хэв шинжийг бүрэн төлөөлж чадах хэсэгт сонгосон ба хөрсний морфологи бичиглэл хийхдээ үе давхарга

\section{СУДАЛГААНЫ ҮР ДУН}

Ой нь модны төрөл, насаар ижил байсан ч хөрс, уур амьсгал, ой ургамалжилтын мужлал зэрэг ургах орчны онцлогоос шалтгаалан ойн өсөлтийн явц харилцан ургуулах замаар нөөцийг нэмэгдүүлэх, ойжуулалтын ажлын цар хүрээг улам нэмэгдүүлэх шаардлагатай болохыг харуулж байна.

үрлэлт, үрийн чанарт нөлөөлөх байдлыг тодорхойлж, тус бүс нутгийн нөхцөлд үрийн талбайн хөрсний шинж чанарыг тодорхойлоход оршино.

ой ургамалжилтын мужийн Сэлэнгийн хошууны Дэлгэрхааны тойрогт хамаарагдана. Энэ бүс нутагт 700-1200 м өргөгдсөн нам уулс, толгод, тэгш талын ойтой. Ойн доод хил улсын хил орчимд далайн түвшнээс дээш 600 м-т байна.

тус бүрээр хөрсний өнгө, хөрсний зузаан, бүтэц, нягт, чийг, чулуужилт, карбонат, ургамлын үндэсний тархалт, байршил зэргийг тодорхойлсон. Хөрсний химийн шинж чанарын үзүүлэлтийг ШУА-ийн Геоэкологийн хүрээлэнгийн хөрсний лабораторит арга зүйн дагуу гүйцэтгэж, өгөгдөл боловсруулалтыг JMP 5.1, SPSS 17 программыг ашиглан үрийн ургацын үнэлгээ, үрийн чанарын үзүүлэлт болон дээж талбайн хөрсний химийн шинж чанарын үзүүлэлтийн ялгааг нэг хүчин зүйлт дисперсийн шинжилгээгээр (One Way ANOVA) тодорхойлов.

адилгүй байдаг. Ойн бонитетийн ангиллыг тодорхой насны моддын дундаж өндөр хэдий чинээ их байвал тухайн ойн ургах орчны нөхцөл тэр хэмжээгээрээ сайн байна 
гэсэн зарчимд тулгуурлан тогтоодог бөгөөд судалгаа хийсэн газруудын ойн үзүүлэлтийг

Хүснэгт 1-ээр үзүүлэв.

Хүснэгт 1. Моддын таксаиийн дундаж үзүүлэлт

\begin{tabular}{|c|c|c|c|c|c|c|c|c|}
\hline $\begin{array}{l}\text { Дээж } \\
\text { талбай }\end{array}$ & 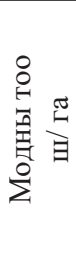 & $\begin{array}{l}\vec{\delta} \\
\stackrel{0}{\circ}= \\
\stackrel{0}{0}\end{array}$ & 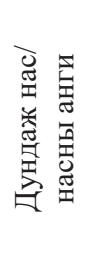 & 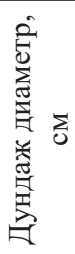 & 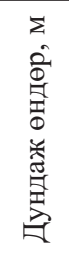 & 鬲岕 & 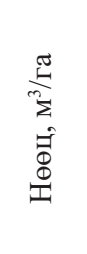 & 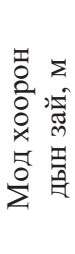 \\
\hline Орос даваа (Од)* & 202 & 0.2 & $24 / I I$ & 15.7 & 8.2 & II & 17.2 & 7.0 \\
\hline Лухам толгой (Лт)* & 49 & 0.2 & 56/III & 35.7 & 16.5 & II & 38.2 & 14.3 \\
\hline Гүн нуур $(Г$ н)* & 130 & 0.2 & 42/III & 25.1 & 11.1 & III & 25.4 & 8.8 \\
\hline $\begin{array}{c}\text { Улаан бургас урд } \\
\text { (Уб урд)* }\end{array}$ & 189 & 0.2 & 39/II & 25.6 & 11.3 & II & 38.3 & 7.3 \\
\hline Талын нуруу (Тн)* & 272 & 0.3 & $32 / \mathrm{II}$ & 18.7 & 8.9 & III & 35.7 & 6.1 \\
\hline Хонд (Хонд)* & 1078 & 0,4 & 23/II & 9.4 & 6.8 & IY & 29.4 & 3.1 \\
\hline $\begin{array}{c}\text { Улаанбургасны хойд } \\
\text { (Уб хойд)* }\end{array}$ & 556 & 0.8 & $88 / Y$ & 24.6 & 22.4 & II & 204.9 & 4.2 \\
\hline Эхэн даваа (Эд)* & 950 & 0.7 & 76/IY & 29.0 & 23.3 & II & 131.6 & 3.2 \\
\hline
\end{tabular}

Ой болон хөрс нь хоорондоо харилцан бие биедээ нөхцөлдсөн чухал холбоотойгоор орших бөгөөд өөрийн нөхцөлд тохирсон өвөрмөц хөрсгүйгээр ой ургадаггүй байхад ойн нөлөөн дор хөрсний үржил шим сайжран өөрчлөгдөж байдаг байна. Тус бүс нутаг дахь нарсан ойн ландшафт экологийн тэнцвэрээ маш хялбархан алддаг байгалийн хамгийн эмзэг тогтолцоо учраас ийм газрын ой модыг огтлох биш, нөхөн үржүүлэх, хамгаалах бодлого барих нь чухал юм [5].

Хөрс нь мод, сөөг ургамлын өсөлт, үрлэлт, үрийн гарц, чанарт хамгийн чухал нөлөө үзүүлж байдаг. Тухайлбал, үржил шим сайтай, ширэгжсэн шавранцар хөрсөнд ургасан нарсан ой ургах орчны нөхцөл I-II бонитетеийн ангид хамаарагдаж байхад, намгархаг хөрсөнд ургасан нас гүйцсэн ой IY ангид хамаарагддаг байна [12]. Хөрс нь ургамлын үндэсний тархалтад нөлөө үзүүлэх ба үржил шимээр баялаг хөрсөнд нарс ургахдаа голлосон хүчирхэг үндэс үүсгэх ба үржил шимээр ядмаг элсэн болон намгархаг хөрсөнд гадаргуугаар тархсан хэвтээ байрлалтай үндэсний системийг үүсгэдэг байна. Гиргидовын судалгаагаар хөрсний тааламжгүй нөхцөл нь нарсны эр цэцэг үүсэх явцыг бүрдүүлэх гол шалтгаан болох бөгөөд эр цэцэг үүсэхэд эм цэцэг Үүсэхээс бага хэмжээний азот, эрдэс бодис шаарддаг байна. Мөн хөрс нь модлогийн чанарт онцгой нөлөөг үзүүлдэг ба үржил шим сайтай хөрсөнд ургасан нарсны модлог сэвсгэр зөөлөн байхад үржил шим багатай хөрсөнд ургасан нарсны модлогийн физик, механик чанар нягт хатуу байдаг [4].

Эгэл нарс нь экологийн хувьд элсэн болон намгархаг хөрстэй, хайрга чулуурхаг хатуу ширүүн нөхцөлд ч дасан зохицож ургах чадвартай өргөн тархацтай юм. Судалгааны бүс нутгийн хөрс нь Монгол орны хөрсний ангиллаар ойн сул чандруулаг элсэн хөрстэй бүсэд хамаарагдана $[5,9$, 10]. Энэхүу хэв шинжийн хөрс нь СэлэнгэОрхоны адаг орчмын элсэн тарамцаг, 
Сэлэнгэ, Онон, Улз голын хөндий дагуух дэнж газар, нам уулсаар тархсан элсэн хурдас дээрх нарсан ойд тогтворжих бөгөөд улсын нийт нутгийн 1.8 хувьтай тэнцэх газрыг хамарна [5].
Судалгааны талбай тус бүрээр хөрсний шинж чанарын үзүүлэлт болох ялзмагийн агууламж, давсжилтыг тодорхойлон Хүснэгт 2-т үзүүлэв.

ХУснэгт 2. Дээж талбайнуудын хөрсний ялзмаг агуулалт болон давсжилтын тодорхойлолт

\begin{tabular}{|c|c|c|c|c|c|c|c|c|c|c|}
\hline \multirow{2}{*}{$\begin{array}{c}\text { Дээж } \\
\text { авсан } \\
\text { гүн, см }\end{array}$} & \multirow{2}{*}{$\begin{array}{c}\text { Ялзмаг, } \\
\text { \% }\end{array}$} & \multirow{2}{*}{$\begin{array}{l}\text { pH 1:5 } \\
\text { усанд }\end{array}$} & \multirow{2}{*}{$\begin{array}{c}\text { Хуурай } \\
\text { Үлдэгдэл, } \\
\text { \% }\end{array}$} & \multicolumn{4}{|c|}{ Анионууд, мг-экв } & \multicolumn{3}{|c|}{ Катионууд, мг-экв } \\
\hline & & & & $\mathrm{CO}_{3}^{-}$ & $\mathrm{HCO}_{3}^{-}$ & $\mathrm{CI}^{-}$ & $\mathrm{SO}_{4}^{2-}$ & $\mathrm{Ca}^{2+}$ & $\mathrm{Mg}^{2+}$ & $\mathrm{Na}^{+}+\mathrm{K}^{+}$ \\
\hline \multicolumn{11}{|c|}{ Од } \\
\hline $0-15$ & 2.31 & 6.71 & 0.0365 & и-гүй & 0.8 & 0.3 & 0.02 & 0.6 & 0 & 0.5 \\
\hline $15-30$ & 2.21 & 6.72 & 0.0298 & и-гүй & 0.6 & 0.3 & 0.02 & 0.4 & 0.1 & 0.4 \\
\hline $30-45$ & 1.82 & 7.03 & 0.0407 & и-гүй & 1.0 & 0.2 & 0.04 & 0.4 & 0.2 & 0.6 \\
\hline $45-60$ & 0.94 & 6.96 & 0.0486 & и-гүй & 1.2 & 0.2 & 0.02 & 0.4 & 0.1 & 0.9 \\
\hline \multicolumn{11}{|c|}{ Лт } \\
\hline $0-15$ & 2.41 & 6.74 & 0.0399 & и-гүй & 0.9 & 0.2 & 0.02 & 0.6 & 0.1 & 0.4 \\
\hline $15-30$ & 2.10 & 6.96 & 0.0468 & и-гүй & 0.9 & 0.5 & 0.02 & 0.6 & 0.1 & 0.7 \\
\hline $30-45$ & 1.81 & 6.41 & 0.0271 & и-гүй & 0.6 & 0.2 & 0.04 & 0.4 & 0.1 & 0.3 \\
\hline $45-60$ & 1.03 & 6.72 & 0.0308 & и-гүй & 0.7 & 0.2 & 0.02 & 0.3 & 0.1 & 0.5 \\
\hline \multicolumn{11}{|c|}{$\Gamma \mathrm{H}$} \\
\hline $0-15$ & 0.92 & 6.64 & 0.0322 & и-гүй & 0.7 & 0.2 & 0.04 & 0.3 & 0.1 & 0.5 \\
\hline $15-30$ & 0.86 & 6.31 & 0.0257 & и-гүй & 0.6 & 0.2 & 0.02 & 0.4 & 0.1 & 0.3 \\
\hline $30-45$ & 0.75 & 6.70 & 0.0297 & и-гүй & 0.6 & 0.2 & 0.04 & 0.2 & 0.1 & 0.5 \\
\hline $45-60$ & 0.69 & 6.72 & 0.0291 & и-гүй & 0.8 & 0.2 & 0.02 & 0.4 & 0.1 & 0.3 \\
\hline \multicolumn{11}{|c|}{ Уб урд } \\
\hline $0-15$ & 0.81 & 7.01 & 0.0333 & и-гүй & 0.8 & 0.2 & 0.02 & 0.4 & 0.1 & 0.5 \\
\hline $15-30$ & 0.35 & 6.62 & 0,0346 & и-гүй & 0.8 & 0.2 & 0.02 & 0.3 & 0.1 & 0.6 \\
\hline $30-45$ & 0.26 & 6.77 & 0.0297 & и-гүй & 0.6 & 0.2 & 0.04 & 0.2 & 0.1 & 0.5 \\
\hline \multicolumn{11}{|c|}{$\mathrm{TH}$} \\
\hline $0-15$ & 0.69 & 7.11 & 0.0405 & и-гүй & 0.8 & 0.3 & 0.04 & 0.4 & 0 & 0.7 \\
\hline $15-30$ & 0.61 & 6.82 & 0.0272 & и-гүй & 0.8 & 0.2 & 0.02 & 1.0 & 0 & 0.02 \\
\hline \multicolumn{11}{|c|}{ Хонд } \\
\hline $0-15$ & 0.92 & 6.94 & 0.0383 & и-гүй & 0.7 & 0.2 & 0.02 & 0.4 & 0.1 & 0.6 \\
\hline $15-30$ & 0.84 & 6.55 & 0.0347 & и-гүй & 0.8 & 0.2 & 0.03 & 0.4 & 0.1 & 0.6 \\
\hline $30-45$ & 0.68 & 6.67 & 0.0358 & и-гүй & 0.6 & 0.2 & 0.04 & 0.3 & 0.1 & 0.5 \\
\hline \multicolumn{11}{|c|}{ Уб хойд } \\
\hline $0-15$ & 0.71 & 6.51 & 0.0291 & и-гүй & 0.8 & 0.02 & 0.02 & 0.4 & 0.1 & 0.34 \\
\hline $15-30$ & 0.62 & 7.14 & 0.0367 & и-гүй & 1.4 & 0.3 & 0.02 & 0.6 & 0 & 1.12 \\
\hline $30-45$ & 0.41 & 6.91 & 0.0271 & и-гүй & 0.6 & 0.2 & 0.04 & 0.4 & 0.1 & 0.34 \\
\hline
\end{tabular}




\begin{tabular}{|c|c|c|c|c|c|c|c|c|c|c|}
\hline \multicolumn{10}{|c|}{ Эд } \\
\hline $0-15$ & 2.45 & 6.71 & 0.0365 & и-гүй & 0.8 & 0.3 & 0.02 & 0.6 & 0 & 0.5 \\
\hline $15-30$ & 2.46 & 6.75 & 0.0298 & и-гүй & 0.6 & 0.3 & 0.02 & 0.4 & 0.1 & 0.4 \\
\hline $30-45$ & 1.88 & 7.07 & 0.0407 & и-гүй & 1.0 & 0.2 & 0.04 & 0.4 & 0.2 & 0.6 \\
\hline $45-60$ & 0.81 & 6.93 & 0.0486 & и-гүй & 1.2 & 0.2 & 0.02 & 0.4 & 0.1 & 0.9 \\
\hline
\end{tabular}

Хүснэгтэс үзэхэд судалгааны талбайнуудын 100 г хөрсөнд агуулагдах ялзмагийн агууламж бага хангагдсан, хөрсний уусмалын орчин дунджаар $\mathrm{pH}$ 6.8 буюу саармаг шинжтэй, хөрсний бүх үе давхаргадаа карбонат $\left(\mathrm{CO}_{2}\right)$ илрээгүй, болохыг харуулж байна.

хөрс давсжаагүй байгаа нь ургамал ургахад тохиромжтой нөхцөл бүрдсэн хэдий ч үрлэлтийн хэмжээг нэмэгдүүлэх, үрийн чанарыг сайжруулахын тулд хөрсний үржил шимийг нэмэгдүүлэх шаардлагатай

ХҮснэгт 3. Хөрсний механик бүрэлдэхүҮн

\begin{tabular}{|c|c|c|c|c|c|c|c|c|}
\hline \multirow{2}{*}{ 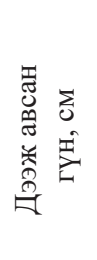 } & \multicolumn{7}{|c|}{ Жижиг ширхэгүүдийн диаметр,\% } & \multirow[b]{2}{*}{$\begin{array}{c}\text { Механик } \\
\text { бүрэлдэхүүний нэр } \\
\text { (Охотинагийн ангиллаар) }\end{array}$} \\
\hline & $\begin{array}{l}n \\
0 \\
0 \\
0 \\
-1\end{array}$ & 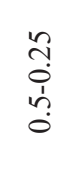 & $\begin{array}{l}2 \\
0 \\
0 \\
\stackrel{1}{1} \\
0\end{array}$ & $\begin{array}{l}ت \\
0 \\
0 \\
\dot{1} \\
0 \\
0\end{array}$ & $\begin{array}{l}2 \\
8 \\
\dot{0} \\
0 \\
1 \\
\vdots \\
0\end{array}$ & $\begin{array}{l}\overline{8} \\
\dot{0} \\
0 \\
\stackrel{1}{o} \\
\dot{8} \\
\dot{0}\end{array}$ & $\begin{array}{l}\bar{\delta} \\
\dot{\circ} \\
\dot{v}\end{array}$ & \\
\hline \multicolumn{9}{|c|}{ Од } \\
\hline $0-15$ & 0.1 & 3.0 & 7.9 & 67.6 & 17.1 & 2.0 & 2.4 & Элс \\
\hline $15-30$ & 3.0 & 5.5 & 40.3 & 36.4 & 1.6 & 13.1 & 0.5 & Элс \\
\hline $30-45$ & 0.2 & 33.1 & 34.6 & 25.8 & 6.0 & 0 & 0.4 & Элс \\
\hline $45-60$ & 0.2 & 26.5 & 32.7 & 25.5 & 11.9 & 0 & 0.2 & Элс \\
\hline \multicolumn{9}{|c|}{ Лт } \\
\hline $0-15$ & 3.1 & 7.9 & 11.8 & 21.0 & 34.5 & 12.2 & 9.5 & Тоосорхог хүнд элсэнцэр \\
\hline $15-30$ & 1.3 & 11.2 & 16.7 & 20.9 & 29.7 & 3.7 & 16.4 & Тоосорхог хүнд элсэнцэр \\
\hline $30-45$ & 0.9 & 9.1 & 17.6 & 22.6 & 31.8 & 5.3 & 12.7 & Тоосорхог хүнд элсэнцэр \\
\hline $45-60$ & 3.7 & 34.8 & 27.0 & 14.3 & 9.9 & 3.2 & 7.2 & Элсэнцэр \\
\hline \multicolumn{9}{|c|}{$\Gamma_{\mathrm{H}}$} \\
\hline $0-15$ & 0.1 & 3.0 & 7.9 & 67.6 & 17.1 & 2.0 & 2.4 & Элс \\
\hline $15-30$ & 3.0 & 5.5 & 40.6 & 36.4 & 1.6 & 13.1 & 0.5 & Элс \\
\hline $30-45$ & 0.2 & 33.1 & 34.6 & 25.8 & 6.0 & 0 & 0.4 & Элс \\
\hline $45-60$ & 0.2 & 26.5 & 32.7 & 25.5 & 11.9 & 0 & 0.2 & Элс \\
\hline \multicolumn{9}{|c|}{ Уб урд } \\
\hline $0-15$ & 1.5 & 73.5 & 0.2 & 10.5 & 4.8 & 4.0 & 5.6 & Элсэнцэр \\
\hline $15-30$ & 0.5 & 25.2 & 46.7 & 12.4 & 8.7 & 0.8 & 5.6 & Элсэнцэр \\
\hline $30-45$ & 0.3 & 41.0 & 39.1 & 10.1 & 3.6 & 2.8 & 3.2 & Элс \\
\hline \multicolumn{9}{|c|}{ Тн } \\
\hline $0-15$ & 3.0 & 5.53 & 0.18 & 75.0 & 11.9 & 0 & 4.4 & Элс \\
\hline $15-30$ & 0.8 & 55.5 & 0.15 & 31.2 & 6.75 & 3.18 & 2.4 & Элс \\
\hline
\end{tabular}




\begin{tabular}{|c|c|c|c|c|c|c|c|c|}
\hline \multicolumn{1}{|c|}{ Хонд } \\
\hline $0-15$ & 1.4 & 73.6 & 0.3 & 11.6 & 4.7 & 3.9 & 5.5 & Элсэнцэр \\
\hline $15-30$ & 0.6 & 26.3 & 47.6 & 13.2 & 9.8 & 0.7 & 5.4 & Элсэнцэр \\
\hline $30-45$ & 0.4 & 39.0 & 40.1 & 10.6 & 3.5 & 2.6 & 3.6 & Элс \\
\hline \multicolumn{10}{|c|}{ Уб хойд } \\
\hline $0-15$ & 1.5 & 23.3 & 30.1 & 18.1 & 19.5 & 2.0 & 5.6 & Элсэнцэр \\
\hline $15-30$ & 0.9 & 27.4 & 31.9 & 22.3 & 15.9 & 1.2 & 0.4 & Элс \\
\hline $30-45$ & 0.7 & 22.1 & 30.4 & 32.5 & 12.7 & 1.2 & 0.4 & Элс \\
\hline \multicolumn{10}{|c|}{ Эд } \\
\hline $0-15$ & 3.2 & 7.8 & 11.9 & 31.5 & 27.6 & 5.3 & 12.7 & Тоосорхог хүнд элсэнцэр \\
\hline $15-30$ & 0.9 & 11.6 & 16.4 & 26.6 & 22.8 & 8.0 & 13.8 & Хөнгөн шавранцар \\
\hline $30-45$ & 0.8 & 8.8 & 17.2 & 23.4 & 33.4 & 3.7 & 12.7 & Тоосорхог хүнд элсэнцэр \\
\hline $45-60$ & 3.6 & 31.0 & 27.3 & 17.9 & 13.1 & 1.6 & 5.6 & Элсэнцэр \\
\hline
\end{tabular}

Хөрсний механик бүрэлдэхүүнийг тодорхойлоход элсэн болон элсэнцэр хөрс зонхилж байгаа (Хүснэгт 3) бөгөөд ийм бүрэлдэхүүнтэй хөрсний хувьд ус болон салхины элэгдэл, эвдрэлд харьцангуй тэсвэр муутай, хөнгөн фракцид хамаардаг. Органик бодисын агууламж багатай элсэнцэр болон элсэн хөрс муу барьцалдсан, хамгийн хэврэг агрегат үүсгэх бөгөөд ийм хэврэг шинжийг хадгалж байгаа нь нарсан ойг огтолсны дараа үржил шимт хөрс биш элэгдэл эвдрэлд тэсвэр муутай элс үүсэх нөхцөлийг бүрдүүлдэг байна.

Судалгааны талбайн хөрсний хими, физикийн шинж чанарын үзүүлэлтүүдийн хооронд статистикийн хувьд ялгаа байгаа эсэхийг нэг хүчин зүйлт вариансын анализаар шинжилж хүснэгтэнд үзүүлэв.

ХУснэгт 4. Хөрсний химийн ҮзҮҮлэлт, (ANOVA)

\begin{tabular}{|c|c|c|}
\hline Үзүүлэлт & (df) & F value \\
\hline Хөрсний рН & 7 & $1.1^{\mathrm{ns}}$ \\
\hline Хуурай үлдэгдэл,\% & 7 & $1.1^{\mathrm{ns}}$ \\
\hline Ялзмаг, \% & 7 & $7.7^{* * *}$ \\
\hline Механик бүрэлдэхүүн,\% & 7 & $8.6^{* * *}$ \\
\hline Гидрокарбонат, $\mathrm{HCO}_{3}^{-}$ & 7 & $0.7^{\mathrm{ns}}$ \\
\hline $\mathrm{Cl}^{-}$ & 7 & $0.8^{\mathrm{ns}}$ \\
\hline Сульфат, $\mathrm{SO}_{4}^{2-}$ & 7 & $0.1^{\mathrm{ns}}$ \\
\hline $\mathrm{Ca}^{2+}$ & 7 & $2.0^{\mathrm{ns}}$ \\
\hline $\mathrm{Mg}^{2+}$ & 7 & $8.2^{* * *}$ \\
\hline $\mathrm{Na}^{+}+\mathrm{K}^{+}$ & 7 & $0.4^{\mathrm{ns}}$ \\
\hline
\end{tabular}


Хөрсний хими, физикийн үзүүлэлтүүдэд хийсэн нэг хүчин зүйлт вариансын анализын шинжилгээнээс үзэхэд хөрсний $\mathrm{pH}$, хуурай үлдэгдэл, анионууд $\left(\mathrm{HCO}_{3}, \mathrm{Cl}\right.$, $\mathrm{SO}_{4}^{2-}$ ) нь талбай тус бүрд статистикийн хувьд $\mathrm{P}<0.1$ буюу ялгаагүй, хөрсний ялзмаг агууламж болон механик бүрэлдэхүүний хувьд $\mathrm{P}<0.001$ буюу статистикийн хувьд ялгаатай байна. Хөрсний үржил шимийн үндсэн үзүүлэлтүүдийн нэг нь ялзмаг агуулалт юм [2]. Манай орны хөрсний унаган үржил шимийн түвшин доогуур байдаг бөгөөд ялзмагийн хэмжээ дунджаар 3.0 хувиас хэтрэхгүй, элсэнцэр хөрсөнд 1.5-2.0 хувь байдгийг тогтоосон байна [5]. Хүснэгтээс үзэхэд ялзмаг агууламж дунджаар Орос даваанд 1.82 хувь, Лухам толгойд 1.83 хувь, Гүн нуурт сонгосон талбайд 0.81 хувь, Улаан бургасны талбайд 0.71 хувь, Талын нурууны талбайд 0.65 хувь буюу 100 г хөрсөнд агуулагдах ялзмагийн агууламж дунджаар $1.16 \%$ үржил шимээр ядмаг байна. Хөрс ялзмагаар ядуу байгаа нь ургамлын үндэс зонхилон хуралдах Yе давхаргад органик үлдэгдэл бага, ялзралтын үйл явц дутуу бага явагдаж байгаатай холбоотой бөгөөд судалгааны бүс нутагт хуурайсаг-алаг өвст, хошоон бут алаг өвст, улалж алаг өвст, үетэн-алаг өвст хэв шинжийн ой зонхилон тархах ба өвслөг ургамлан бүрхэвч ерөнхийдөө сул хөгжсөн байгаа нь хөрсний шим тэжээл бүрэлдэх явцад тодорхой хэмжээгээр нөлөө үзүүлж байна.

Ургах орчны нөхцөлийн (бонитет) II ангид хамаарах талбайн хувьд физик шаврын агууламжийн эзлэх хувь их бөгөөд механик бүрэлдэхүүний хувьд тоосорхог хүнд элсэнцэр, 100 г хөрсөнд агуулагдах ялзмаг агууламж $1.32 \%$, байхад бонитетийн III ангид хамаарах талбайн хувьд элсэнцэр механик бүрэлдэхүүнтэй, ялзмаг $0.73 \%$, бонитетийн IY ангийн талбайн хувьд элсэн механик бүрэлдэхүүн зонхилж, ялзмаг агууламж $0.65 \%$ байна. Эндээс үзэхэд ургах орчны нөхцөл сайжрах тусам хөрсний шинж чанарын ҮзҮүлэлтүүд сайжирч байгаа бөгөөд ойн үрийн байнгын талбайг сонгохдоо бонитетийн II-III ангийн ойг сонгох нь тохиромжтой байна.

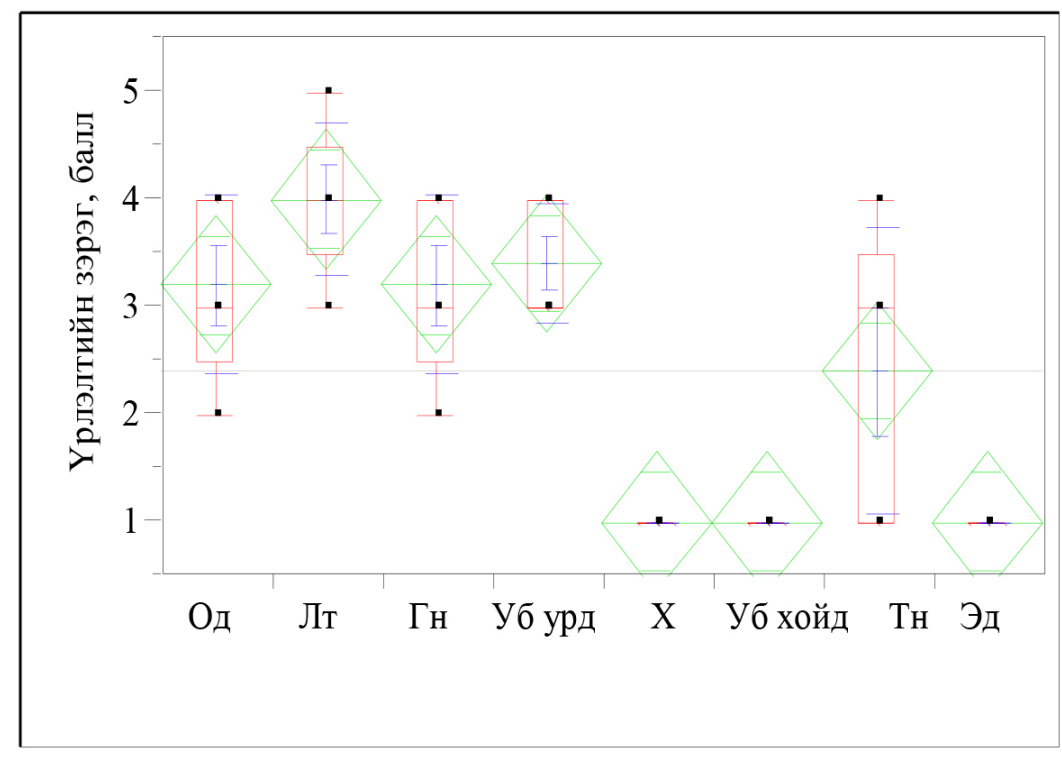

Зураг 1. Судалгааны талбайн үрийн ургащын үнэлгээний харьиуулалт $(F=15.314, d f=7, p=0.0001)$ 
Моддын үрлэлтийн явцыг нэг хүчин зүйлт дисперсийн шинжилгээгээр илэрхийлэхэд талбайнуудын үрлэлт нь статистикийн хувьд $(\mathrm{p}=0.001)$ ялгаатай байна. Үр боловсрох явцад олон хүчин зүйл нөлөөлдөг тухайлбал, тухайн үеийн уур амьсгалын нөхцөл, ургамал ургалтын үеийн чийгийн нөхцөл, хөрсний үржил шим, модны нас, ургах орчны нөхцөл зэрэг олон хүчин зүйлээс хамаарна $[3,4]$. Судалгааны талбайд Корчагины ангиллаар үрлэлтийн байдлыг тодорхойлоход 3-4 баллын үнэлгээтэй байв.

Судалгааны материалаас харахад үржил шимээр баялаг, чийгэрхэг хөрсөнд ургасан ойн үр өгөлтийн хугацаа хурдасдаг байхад үржил шимээр ядмаг, хуурай хөрсөнд ургасан ойн үр өгөлт удааширдаг $[6,16]$ бөгөөд үрлэлтийн үнэлгээнээс үзэхэд Од, Лт, Гн, Уб урд талбайнуудын үрийн ургац 3-4 баллын үнэлгээтэй буюу харьцангуй сайн үзүүлэлттэй ба эдгээр талбайн хувьд 1 га дахь моддын тоо цөөн, насны II-III ангид хамаарах дунд насны, хөрсний шинж чанарын үзүүлэлт болох ялзмаг агууламжийн хувьд бусад талбайгаасаа харьцангуй их байна. Үрлэлт болон дээж талбайн хөрсний ялзмаг агууламжийн үзүүлэлтийн хамаарлыг тооцохын тулд корреляцын шинжилгээ хийж коэффициентийг тооцоход $\mathrm{r}=0.65$ буюу мэдэгдэхүйц хамааралтай байна. Энэ нь Черепниний хэдий чинээ үржил шимтэй хөрсөнд ургасан ой, модны үрийн ургац баялаг байна гэсэн [15] судалгааны дүнтэй ижил байна.

Үрийн дээж цуглуулсан талбай тус бүрийн үрийн чанарын үзүүлэлтүүдийн ялгааг нэг хүчин зүйлт диспесрийн шинжилгээгээр илэрхийлэхэд соёололт, ургах эрчим, 1000 үрийн жингийн үзүүлэлтээрээ статистикийн хувьд $(\mathrm{p}=0.001)$ ялгаатай байна (Хүснэгт 5).

ХУснэгт 5. Үрийн чанарын ҮзҮҮлэлт

\begin{tabular}{|c|c|c|c|}
\hline Дээж талбай & Соёололт, $\%$ & Ургах эрчим, $\%$ & 1000 үрийн жин, г \\
\hline Од & $92.5 \pm 0.6$ & $65.6 \pm 2.1$ & $8.0 \pm 0.2$ \\
\hline Лт & $82.2 \pm 2.8$ & $56.8 \pm 2.6$ & $5.7 \pm 0.1$ \\
\hline Гн & $86.4 \pm 0.9$ & $60.9 \pm 1.3$ & $7.2 \pm 0.3$ \\
\hline Уб урд & $81.2 \pm 1.8$ & $59.4 \pm 1.9$ & $6.4 \pm 1.5$ \\
\hline Тн & $73.4 \pm 0.8$ & $45.7 \pm 1.8$ & $5.6 \pm 1.5$ \\
\hline
\end{tabular}

Үрийн соёололтоос Үзэхэд Орос даваанд хамгийн өндөр $(92.5 \%)$, Талын нуруунд хамгийн бага үзүүлэлттэй (72.2\%) байгаа бөгөөд энэ нь ургах орчны нөхцөл болон хөрсний шинж чанарын үзүүлэлтээс хамаарч ялгаатай байгааг харуулж байна. Хөрсний шинж чанарын үзүүлэлтээр Орос давааны талбайн хөрсний физик шаврын агууламжийн эзлэх хувь их бөгөөд механик бүрэлдэхүүний хувьд тоосорхог хүнд элсэнцэр, 100 г хөрсөнд агуулагдах ялзмаг агууламж $1.82 \%$, байхад Талын нурууны талбайн хувьд физик шаврын агууламжийн эзлэх хувь бага буюу элсэн механик бүрэлдэхүүнтэй, ялзмаг $0.65 \%$ байгаа ба энэ нь ургах орчны нөхцөл, хөрсний шинж чанарын үзүүлэлтүүд нь үрийн чанарт нөлөө үзүүлж байгааг харуулж байна. 
ХУснэгт 6. Урийн чанарын ҮзҮҮлэлтүҮд $(n=45)$

\begin{tabular}{|c|l|c|c|}
\hline № & \multicolumn{1}{|c|}{ Үзүүлэлт } & Чөлөөний зэрэг & Фишерийн шалгуур \\
\hline 1 & Соёололт, $\%$ & 4 & $40.594 * * *$ \\
\hline 2 & Ургах эрчим, \% & 4 & $87.461^{* * *}$ \\
\hline 3 & 1000 үрийн жин, г & 4 & $84.667 * * *$ \\
\hline
\end{tabular}

$P<0.001^{* * *}$ - түвшний ялгааг илэрхийлнэ

Ургах эрчмийг тодорхойлсон дүнгээр Орос даваанд тусгаарласан талбайд хамгийн өндөр (65.6\%), Талын нуруунд хамгийн бага үзүүлэлттэй (45.7\%) байгаa бөгөөд $(\mathrm{F}=87.461, \mathrm{p}=0.001)$ дээж талбайнууд нь ургах эрчмийн үзүүлэлтээрээ статистикийн хувьд ялгаатай байна. Үрийн жин нь ойн моддын удамшлын шинж чанар, ургалтын чанарыг тодорхойлох чухал шинж тэмдгүүдийн нэг юм. Ургах орчны тохиромжгүй нөхцөлд 1000 үрийн жингийн хэлбэлзэл нилээд илрэх ба модны титэм дэх боргоцойн байрлал, модны нас, ойн титэм нийлэлт, цаг уурын онцлогоос хамаарч хэлбэлздэг байна. 1000 үрийн жингийн үзүүлэлт нь удамшлын чухал шинж өөрөөр хэлбэл гадаад орчны хэлбэлзэлд хэдийчинээ бага өртөж, тэсвэрлэж гарах чадварыг илтгэх бөгөөд Орос даваанд хамгийн өндөр (8.0 г), Талын нуруунд хамгийн бага үзүүлэлттэй (5.6 г) байна. Үрийн жингийн үзүүлэлт нь статистикийн хувьд ялгаатай $(\mathrm{F}=84.667, \mathrm{p}=0.001)$ байгаа нь ургах орчны нөхцөл, хөрсний шинж чанарын үзүүлэлтүүд нөлөө үзүүлж байгааг харуулж байна.

\section{ДҮГНЭЛТ}

1. Судалгааны дүнгээр II бонитетийн ойд тоосорхог хүнд элсэнцэр, 100 г хөрсөнд агуулагдах ялзмаг агууламж $1.32 \%$, байхад, III бонитетийн ойд элсэнцэр механик бүрэлдэхүүнтэй, ялзмаг $0.73 \%$, бонитетийн IY ангийн ойд элсэн механик бүрэлдэхүүн зонхилж, ялзмаг агууламж $0.58 \%$ байна. Бонитетийн анги дээшлэх тусам хөрсний шинж чанарын үзүүлэлтүүд сайжирч байна.

2. Хөрсний шинж чанарын хөрсний уусмалын орчин ерөнхийдөө саармаг шинжтэй, 100 г хөрсөнд агуулагдах ялзмаг бага хангагдсан буюу үржил шимээр ядмаг, хөрс давсжаагүй байна. Судалгаа гүйцэтгэсэн бүс нутагт ургамал ургахад тохиромжтой нөхцөл бүрдсэн хэдий ч үрлэлтийн хэмжээг нэмэгдүүлэх, үрийн чанарыг сайжруулахын тулд хөрсний үржил шимийг нэмэгдүүлэх шаардлагатай байна.

үзүүлэлтээр судалгааны талбайнуудын

\section{Ашигласан бүтээлийн жагсаалт}

1. Анучин Н.П. 2004. Лесная таксаиия. Учеб. Для вузов. 6-е изд. -М. ВНИИЛМ, 552 с

2. Баасандорж Я., Бадрах С. 2010. Хээрийн бүсийн бэлчээрийн экологийн зарим асуудал. УБ, х.152

3. Гиргидов Д.Я. 1968. Научные основы и практика создания лесосеменных участков и плантаций сосны в северо-западных областях РСФСР: Дисс...канд. с. -х. Наук.Ленинград:, с. 201-211

4. Гиргидов Д.Я. 1976. Семеноводство сосны на селекиионной основе.- М.: Лесн. Промcmb, $-64 c$

5. Доржготов Д. 2003. Монгол орны хөрс. УБ, 287 х. Доржготов Ж., Лигаа У. 1979. Ой судлал. УБ, х 146-150 
6. Доржготов Ж., Лигаа У. 1979. Ой судлал. УБ, х 146-150

7. Коротков И.А. 1978. Типы лесов Монгольской Народной Республики. // Леса Монгольской Народной Республики. М., Наука, с. 147

8. Корчагин А.А. 1960. Методы учета семеноношения древесных пород и лесных сообществ.-М.: -T.II. с41-132

9. Монгол Улсын үндэсний атлас. 2009. ІІ хэвлэл. УБ.

10. Огородников А.В. Почвы горных лесов МНР.-Новосибирс: Наука, 1981, с.142

11. Ойн газар. 2012.Ойн ажлльн стандарт.//гарын авлага. УБ, х 37-102.

12. Тараканов В.В., Демиденко В.П., Ииутин Я.Н., Бушков Н.Т. 2001. Селекиионное семеноводство сосны обыкновенной в Сибири.-Новосибирск: Наука,-230 c.

13. Тужийн нарсны байгалийн цогцолборт газрын менежментийн төлөвлөгөө. 2010, x.59.

14. Цэдэндаш Г. 1996. Умард Монголын ой-ургамалжситын мужлальн асуудалд. Ой, ан судлальнн хүрээлэнгийн эрд.шин.бүтээл, №2, с. 24-29.

15. Черепнин В.Л. 1960. Изменчивость семян сосны обыкновенной. Новосибирск, Наука, $182 \mathrm{c}$

16. Aniszewska M. 2006. Connection between shape of pine (Pinus sylvestris L.) cones and weight, colour and number of seeds extracted from them. EJPAU, 9(1), №03.

17. International Seed Testing Association (ISTA). 1999. International rules for seed testing. Seed Science and technology, 21 (Suppl.)

18. Tsogtbaatar J. (2004) Deforestation and reforestation needs in Mongolia. Forest Ecology and Management 201 (1):57-63. 